\title{
Study on standardization of starch extraction time from rhizomes of tikhur (Curcuma angustifolia Roxb.)
}

DEO SHANKAR, S. PATEL, M.K. SAHU AND S.C. MUKHERJEE

Received : 12.07.2014; Revised : 08.09.2014; Accepted : 19.09.2014

See end of the Paper for authors' affiliation

Correspondence to :

\section{DEO SHANKAR}

AICRP on Tuber Crops, Shaheed Gundadhoor College of Agriculture and Research Station, Jagdalpur, BASTAR (C.G.) INDIA

Email : deo1975ram@gmail.com
- ABSTRACT : The investigation was conducted at Shaheed Gundadhoor College of Agriculture and Research Station (IGKV), Kumhrawand, Jagdalpur, Bastar, Chhattisgarh. The experiment was undertaken during $1^{\text {st }}$ December to $30^{\text {th }}$ December 2010 and $1^{\text {st }}$ December to $30^{\text {th }}$ December 2011 . The experiment was laid out in Completely Randomized Design (CRD) in which 7 treatments were tested in three replications. High rhizome and starch yielded genotype IGSJT-10-2 of tikhur was selected as an experimental material. The results clearly indicated that the maximum starch yield $167.29 \mathrm{~g} / \mathrm{kg}$ of rhizome was recovered in treatment $\mathrm{T}_{2}$ (starch extraction on 5 days after harvest) and lowest starch yield $127.06 \mathrm{~g} / \mathrm{kg}$ of rhizome was recorded in treatment $T_{7}$ (Starch extraction on 30 days after harvest of rhizomes). The highest starch recovery per cent was recorded in treatment $T_{2}$ and lowest starch recovery per cent was recorded in treatment $T_{7}$. Starch colour observed white in all treatments. In the year 2011-12, highest starch yield 167.73 $\mathrm{g} / \mathrm{kg}$ of rhizome was recorded in treatment $\mathrm{T}_{2}$ and lowest starch yield $123.27 \mathrm{~g} / \mathrm{kg}$ or rhizome was recorded in treatment $T_{7}$. The highest average starch recovery per cent (16.75) of rhizome was also recorded in treatment $T_{2}$ and lowest starch recovery per cent (12.52) rhizome was recorded in treatment $T_{7}$. The low starch yield and starch recovery per cent was recorded when starch extracted one day after harvesting of rhizomes, it may be due to high moisture content of rhizomes and field heat. Gradual reduction of starch yield and starch recovery per cent starch extraction after 5 days may be due to conversion of starch in to sugar due to increasing of temperature.

- KEY WORDS : Tikhur, Curcuma angustifolia Roxb., Starch extraction, Starch recovery, Tikhur processing

- HOW To CITE ThiS PAPER : Shankar, Deo, Patel, S., Sahu, M.K. and Mukherjee, S.C. (2014). Study on standardization of starch extraction time from rhizomes of tikhur (Curcuma angustifolia Roxb.). Internat. J. Agric. Engg., 7(2) : 436-441. 